\title{
A new species of the genus Sarsamphiascus Huys, 2009 (Copepoda: Harpacticoida: Miraciidae) from a sublittoral zone of Hawaii
}

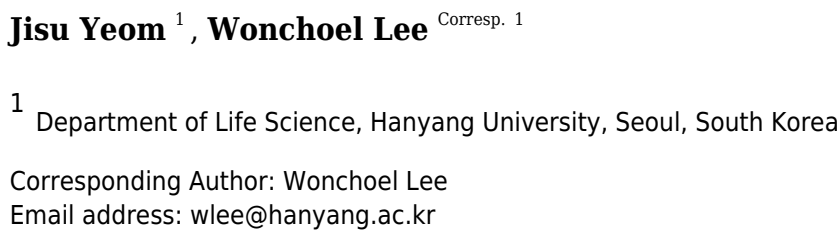

A new species of Sarsamphiascus Huys, 2009 was collected from sandy sediments of Hawaii at 12 - 18 m depth. While the new species, Sarsamphiascus hawaiiensis sp. nov., is morphologically most closely related to $S$. kawamurai (Ueda \& Nagai, 2005), the two species can be distinguished by the combination of the following morphological characteristics: elongated segments of the antennule in the new species, type of outer setae of the P5 exopod (bare in S. kawamurai), position of the inner seta of the P5 exopod in both sexes (more proximal in S. kawamurai), length and type of the setae of female P6 (shorter and bare in S. kawamurai). This is the first species of Sarsamphiascus from Hawaii to be discovered. Molecular analyses of mitochondrial cytochrome c oxidase subunit I (mtCOI) and nuclear $18 \mathrm{~S}$ ribosomal RNA (18S rRNA) genes confirmed that $S$. hawaiiensis and $S$. kawamurai are distinct species. 
1 A new species of the genus Sarsamphiascus Huys, 2009

2 (Copepoda: Harpacticoida: Miraciidae) from a sublittoral zone

3 of Hawaii

4 Jisu Yeom, Wonchoel Lee

5 Department of Life Science, Hanyang University, Seoul, 04763, South Korea

6

7 Corresponding Author:

8 Wonchoel Lee

9 222, Wangsimni-ro, Seongdong-gu, Seoul, 04763, South Korea

10 Email address: wlee@hanyang.ac.kr 
11

12

13

14

15

16

17

18

19

20

21

22

23

24

25

26

27

28

29

30

31

32

33

34

35

36

37

38

39

40

41

42

43

44

45

46

47

48

49

\section{Abstract}

A new species of Sarsamphiascus Huys, 2009 was collected from sandy sediments of Hawaii at 12-18 m depth. While the new species, Sarsamphiascus hawaiiensis sp. nov., is morphologically most closely related to $S$. kawamurai (Ueda \& Nagai, 2005), the two species can be distinguished by the combination of the following morphological characteristics: elongated segments of the antennule in the new species, type of outer setae of the P5 exopod (bare in S. kawamurai), position of the inner seta of the P5 exopod in both sexes (more proximal in S. kawamurai), length and type of the setae of female P6 (shorter and bare in S. kawamurai). This is the first species of Sarsamphiascus from Hawaii to be discovered. Molecular analyses of mitochondrial cytochrome c oxidase subunit I (mtCOI) and nuclear 18S ribosomal RNA (18S rRNA) genes confirmed that $S$. hawaiiensis and $S$. kawamurai are distinct species.

\section{Introduction}

Miraciidae Dana, 1846 is a large family of benthic copepods in the order Harpacticoida (Boxshall \& Halsey 2004). It includes 50 valid genera and 426 species (Song et al. 2007; Wells 2007; Huys \& Mu 2008; Chullarson et al. 2011; Karanovic \& Cooper 2012; Sönmez et al. 2014), most of which were transferred from the former family Diosaccidae by Willen (2002). The members of Miraciidae mostly inhabit the marine environment, although a few species occur in fresh water (Boxshall \& Halsey 2004). In Hawaii, two miraciid species, Schizopera hawaiiensis Kunz, 1995 and Macrosetella gracilis (Dana, 1847), have been recorded (Kunz 1995; Eberl \& Carpenter 2007).

The genus Sarsamphiascus was established by Huys (2009), with Dactylopus minutus Claus, 1863 designated the type species. Amphiascus Sars, 1905 is a senior objective synonym of Paramphiascopsis Lang, 1944 and must be restricted to the species currently included in the latter. Therefore, the new genus Sarsamphiascus was proposed to receive all remaining "orphaned" species included in Amphiascus (Huys 2009).

Amphiascus is a challenging genus in the sense that it is difficult to distinguish among species in this genus due to extreme inter- and intraspecific variation (Lang 1965). Lang (1948) erected four groups (minutus, varians, pacificus, and amblyops) in Amphiascus based on the swimming legs and A2 exopod setation patterns (Hicks 1989). Species in the pacificus-group are characterized by having inner seta on P3 enp-2, no inner seta on P1 exp-2, and seta on A2 exp-1 (Lang 1948). This group contains seven species: S. parvus (Sars G.O., 1906) from Europe, Asia and America; S. kawamurai (Ueda \& Nagai, 2005) from East Asia and Turkey; S. undosus (Lang, 1965) from America; S. pacificus (Sars G.O., 1905) from Europe and New Zealand; $S$. sinuatus (Sars G.O., 1906) from Europe and America; and S. humphriesi (Roe, 1960) from Ireland. Each habitat and the distinguishing features of the pacificus-group and type species of the genus are shown in Table 1. We focused on the characteristics of female A1, A2, P5 and caudal terminal setae in this table. In the pacificus-group, the taxonomic validity of $S$. humphriesi (Roe, 1960) is uncertain because of the absence of inner seta on P2-P3 exp-1. 
50

51

52

53

54

55

56

57

58

59

60

61

62

63

64

65

66

67

68

69

70

71

72

73

74

75

76

77

78

79

80

81

82

83

84

85

86

87

88

Today, there are 31 valid species and two inquirendum species in the genus worldwide (Wells 2007; Huys 2009). A new species of Sarsamphiascus was collected from SCUBA diving in Hawaii, U.S.A. Present study aims to describe the new species and to present an updated identification key to species of Sarsamphiascus.

\section{Materials \& Methods}

Specimens. - Specimens of the new species were collected from the Horseshoe Reef site of Oahu Island, Hawaii at 12-18 m depth on 6 August 2015 and 28 September 2018. Samples were collected by Wonchoel Lee.

Sediment samples were collected by SCUBA diving, sieved through a $38 \mu \mathrm{m}$ sieve, and fixed with $99 \%$ ethanol. Harpacticoids were sorted under a dissecting microscope and stored in $99 \%$ ethanol. Harpacticoids were identified following Huys et al. (1996) and Wells (2007) using a compound microscope and 400-1,000x magnification. All drawings were prepared using a drawing tube on an Olympus BX51 differential interference contrast microscope.

Scanning electron microscopy (SEM). - In total, seven specimens were prepared for SEM. Materials were photographed using a Hitachi S-4700 scanning electron microscope at Eulji University and COXEM EM-30 at Hanyang University. Digital photographs were processed and combined into plates using Adobe Photoshop CS6. To prepare specimens for SEM, they were transferred into pure isoamyl-acetate, critical-point dried, mounted on stubs, coated in gold, and observed under SEM on the in-lens detector at an accelerating voltage of $10.0 \mathrm{Kv}$ and $15.0 \mathrm{Kv}$ and working distance between 7.0 to $13.4 \mathrm{~mm}$.

The descriptive terminology of Huys et al. (1996) was adopted. Abbreviations used in the text are as follows: A1, antennule; A2, antenna; ae, aesthetasc; exp, exopod; enp, endopod; P1-P6, first to sixth thoracopod; exp (enp)-1 $(2,3)$ to denote the proximal (middle, distal) segment of a three-segmented ramus. Specimens were deposited in the National Marine Biodiversity Institute of Korea (MABIK). Scale bars in figures are in $\mu \mathrm{m}$.

We received $S$. kawamurai specimens from the MABIK marine zooplankton resource bank (REP000000000911) for comparative purposes. These specimens were collected from the West sea (Shin-An, SA / MRS002000107530) and the East sea (Go-Seong, GS / MRS002000107525; Yeong-Deok, YD / MRS002000107507; Gi-Jang, GJ / MRS002000107528) of South Korea and cultured by the Marine Zooplankton Resources Deposit Registration Preservation agency. Three of these specimens were randomly used to measure lengths of morphological features.

DNA extraction and amplification. - For DNA extraction and amplification, specimens were transferred into ultrapure water for two hours to remove ethanol. Specimens were then prepared for non-destructive DNA extraction in worm lysis buffer (Williams et al. 1992). Specimens were placed in tubes containing $25 \mu \mathrm{l}$ lysis buffer and placed in a Takara thermocycler (Takara, Otsu, Shiga, Japan) with the following settings: $65^{\circ} \mathrm{C}$ for $15 \mathrm{~min}, 95^{\circ} \mathrm{C}$ for $20 \mathrm{~min}$ and $15^{\circ} \mathrm{C}$ for $2 \mathrm{~min}$. After this, specimens were kept for morphological identification and describing them after genetically confirming. Unpurified total genomic DNA was kept at $-20^{\circ} \mathrm{C}$ for long-term storage. 
89

90

91

92

93

94

95

96

97

98

99

100

101

102

103

104

105

106

107

108

109

110

111

112

113

114

115

116

117

118

119

120

121

122

123

124

125

126

127

128

Fragments from two genes, the nuclear 18S ribosomal RNA (18S rRNA) and mitochondrial cytochrome oxidase subunit I (mtCOI) genes, were amplified using PCR premix (BiONEER Co.) and $3 \mu \mathrm{l}$ of genomic DNA as template. PCR primers 18S-F1, 18S-F3, 18S-R7, and 18S-R9 (Yamaguchi \& Endo 2003) were used to amplify 18S ribosomal RNA. MtCOI was amplified with Cop-COI-2189 and LCO1490 primers (Bucklin et al. 2010). For 18S, the amplification protocol consisted of an initial denaturation at $94^{\circ} \mathrm{C}$ for 5 min followed by 33 cycles of denaturation at $94^{\circ} \mathrm{C}$ for $30 \mathrm{sec}$, annealing at $47^{\circ} \mathrm{C}$ for $30 \mathrm{sec}$, and extension at $72^{\circ} \mathrm{C}$ for $1 \mathrm{~min}$; this was followed by a final extension step at $72^{\circ} \mathrm{C}$ for $10 \mathrm{~min}$. For $\mathrm{mtCOI}$, the amplification protocol consisted of an initial denaturation at $94^{\circ} \mathrm{C}$ for $5 \mathrm{~min}$ followed by 40 cycles of denaturation at $94^{\circ} \mathrm{C}$ for $1 \mathrm{~min}$, annealing at $45^{\circ} \mathrm{C}$ for $2 \mathrm{~min}$, and extension at $72^{\circ} \mathrm{C}$ for $3 \mathrm{~min}$; this was followed by a final extension step at $72^{\circ} \mathrm{C}$ for $10 \mathrm{~min}$ (Bucklin et al. 2010). Successful amplification was confirmed by electrophoresis on a $1 \%$ agarose gel.

PCR products were sent to Macrogen (Seoul, Korea) for purification and DNA sequencing. DNA was sequenced on an ABI automatic capillary sequencer using the same sets of primers as used for amplification. All obtained sequences were visualized using Finch TV version 1.4.0 (https://digitalworldbiology.com/FinchTV; Geospiza Inc., USA).. The quality of each sequence was evaluated and low resolution peaks were checked by comparing forward and reverse strands. BLAST searches revealed that the obtained sequences were copepod in origin and not contaminants. Sequence information from this study was deposited in the NCBI database (18S MN496455, MN496456; MN541391-MN541394 and mtCOI - MN507530; MN542379, MN542380).

Phylogenetic analyses. - An additional 43 sequences were downloaded from GenBank and included in our analyses (Table 2). Obtained sequences were checked manually and aligned by the ClustalW algorithm (Thompson et al. 1994) in MEGA version 7.0 (Kumar et al. 2016). Phylogenetic analyses were performed using Neighbor-Joining (NJ), Maximum Likelihood (ML) and Bayesian Inference (BI) approaches. NJ analysis used the Kimura two-parameter model (K2P) (Kimura 1980; Nei \& Kumar 2000) with uniform rates. ML analysis used the K2+G+I model based on the model test result in MEGA. One thousand bootstrap replicates were performed to obtain a relative measure of node support for the resulting trees. A BI tree was constructed with MrBayes v3.2.6 x64 (Ronquist et al., 2012) based on the following model parameters obtained using jModelTest 2.1.10 (Darriba et al., 2012): nst = 6, rates = gamma, and ncat $=4$. Markov Chain Monte Carlo $(\mathrm{MCMC})$ was run with the following parameters: nchains $=$ 4 , ngen $=1,000,000$, samplefreq $=100$, and printfreq $=1000$. ML and BI trees were visualized using FigTree v1.4.2. Average pairwise distances were also computed in MEGA version 7.0 using the K2P model. All trees were rooted with thalestrid sequences.

The electronic version of this article in Portable Document Format (PDF) will represent a published work according to the International Commission on Zoological Nomenclature (ICZN), and hence the new names contained in the electronic version are effectively published under that Code from the electronic edition alone. This published work and the nomenclatural acts it contains have been registered in ZooBank, the online registration system for the ICZN. The 
129

130

131

132

133

134

135

136

137

138

139

140

141

142

143

144

145

146

147

148

149

150

151

152

153

154

155

156

157

158

159

160

161

162

163

164

165

166

167

ZooBank LSIDs (Life Science Identifiers) can be resolved and the associated information viewed through any standard web browser by appending the LSID to the prefix http://zoobank.org/. The LSID for this publication is: [urn:1sid:zoobank.org:pub:B93346F0-3942-4CC9-A6EDD437D899239F]. The online version of this work is archived and available from the following digital repositories: PeerJ, PubMed Central, and CLOCKSS.

\section{Results}

Order Harpacticoida Sars G.O., 1903

Family Miraciidae Dana, 1846

Genus Sarsamphiascus Huys, 2009

Sarsamphiascus hawaiiensis sp. nov. (Figs. 1-6)

urn:1sid:zoobank.org:act:BACD08DD-8F16-4106-8FCE-F4C1ED96A8AC

Type locality. - Horseshoe Reef site, Oahu Island, Hawaii, U.S.A., 21 ${ }^{\circ} 28^{\prime} 35.93$ ” N, 158 13 '30.57" W (depth: $14 \mathrm{~m}$; sandy sediment; water temperature: $26-30^{\circ} \mathrm{C}$ ).

Material examined. — Holotype 1우 (MABIKCR00246491) Allotype 1ð (MABIKCR00246492). Paratype 2우우 1ð on three slides (MABIKCR00246493MABIKCR00246495), 2우우 dissected on 14 slides (MABIKCR00246496, MABIKCR00246497), and 2ðð dissected on six slides (MABIKCR00246498,

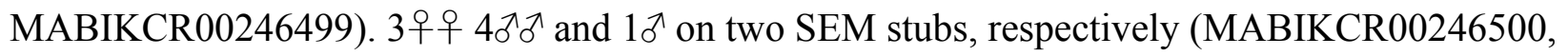
MABIKCR00246501). Sampled by SCUBA diving on 6 Aug 2015 and 30 Sep 2018.

Description of female. - Total body length $544.3 \mu \mathrm{m}(\mathrm{n}=3)$ (Figs. 1A, B); body slender, cylindrical, slightly tapering behind. Cephalosome bell-shaped. Rostrum (Figs. 1A, 2C). Large, tapering distally, about 2.8 times longer than broad, defined at base, reaching to distal margin of second antennulary segment; with two small sensilla. Anal somite (Fig 1A) with row of spinules along distal margin; anal operculum well developed, semicircular, with fine setulae along its posterior margin.

Caudal ramus (Figs. 1A, D, 6E, F). About 0.7-0.8 times as long as greatest width, armed with spinules inner distally and with short setules on distal margin (arrowed in Fig. 6F); each ramus armed with seven setae; seta I and seta II developed, located near distal corner of lateral margin; seta I spiniform; seta III bare, longer than seta II, located near distal corner of ventral surface; seta IV well developed, bipinnate, seta IV longer than half of seta V, seta V as long as urosome; both terminal caudal setae with fracture plane; seta VI bare, 1.5 times as long as seta II, slightly curved inward at its base; seta VII short, bare, located on dorsal surface of caudal ramus.

Antennule (Fig. 2C). Eight-segmented, slender; segment-1 with two spinules on inner edge; segment-2 about twice as long as broad, about 1.4 times as long as segment-1, and about 1.8 times as long as segment-3; segment-4 1.5 times as long as segment-3. Armature formula: 1-[1 
168

169

170

171

172

173

174

175

176

177

178

179

180

181

182

183

184

185

186

187

188

189

190

191

192

193

194

195

196

197

198

199

200

201

202

203

204

205

206

bare], 2-[8 bare +3 pinnate], 3-[7 bare], 4-[4 bare + ae], 5-[2 bare], 6-[4 bare], 7-[4 bare], 8-[7 bare + ae]. Aesthetasc on segment- 4 fused basally with adjacent seta and about 2.3 times as long as distal four segments combined.

Antenna (Figs. 2D, 6B). Endopod two-segmented, enp-1 bearing pinnate seta, enp-2 with two spiniform setae and bare seta posteriorly, seven setae terminally, four geniculate setae, two bare setae and slightly unipinnate seta; exopod three-segmented, exp-1 about three times longer than broad, bearing pinnate seta distally, exp-2 very short without seta, exp-3 about 2.5 times longer than broad with seta proximally and three setae distally.

Mandible (Fig. 2E). Gnathobase bearing chitinous projection on ventral surface; palp with three setae and setule rows; exopod two-segmented, exp-1 with pinnate seta and bare seta, exp-2 with two bare setae and pinnate seta; endopod one-segmented with two proximal and six distal setae.

Maxillule (Fig. 2F). Praecoxal arthrite bearing seven elements distally with two pinnate setae and two bare setae on anterior surface; coxa with two setae; basis with six setae; endopod bearing four setae; exopod bearing two pinnate setae.

Maxilla (Fig. 2G). Three endites of syncoxa with four, two, two setae, respectively; basis with two thick setae and thin seta; endopod with six setae.

Maxilliped (Fig. 2H). Subchelate; syncoxa with two long setae, relatively short seta and several rows of spinules; basis pectinate with several long spinules on the medial surface, twice as long as broad, bearing two bare setae; endopod elongate, with strong claw, bare seta, and unipinnate seta.

In P1 - P4, all rami three-segmented and coxa ornamented with several rows of spinules. Setal formula of the new species is shown in Table 3.

P1 (Fig. 3A). Basis inner margin with setules and armed with bipinnate spine distally. Exp-1 inner margin bare, exp-1 and exp-2 with bipinnate outer spine and ornamented with spinules along outer margin, exp-2 and exp-3 inner margin with setules without inner seta, exp-3 with three outer spines and long geniculate seta and relatively short, geniculate and unipinnate setae distally. Enp-1 longer than exopod, about six times longer than wide with inner seta distally, inner and outer margin ornamented with setules; enp-2 small, ornamented with spinules along distal margin, without inner seta; enp-3 longer than enp-2, outer margin ornamented with spinules, bearing slender seta at inner distal corner, unipinnate claw-like spine and relatively short geniculate seta apically.

P2 (Fig. 3B). Basis with bipinnate outer spine.Exp-1 with seta at distal inner margin, setules on inner distal margin, exp-2 with inner seta at distal, inner margin ornamented with setules, both exp-1 and exp-2 with bipinnate outer spine and outer margin ornamented with spinules, exp-3 with plumose inner seta, long plumose seta at inner terminal, long seta with plumose inner side and pinnate outer side at outer terminal and three outer spines, proximal inner margin ornamented with setules, proximal outer margin ornamented with spinules. Endopod about as long as exopod, enp-1 with plumose inner seta, outer margin ornamented with setules; enp-2 
207

208

209

210

211

212

213

214

215

216

217

218

219

220

221

222

223

224

225

226

227

228

229

230

231

232

233

234

235

236

237

238

239

240

241

242

243

244

245

with two inner setae; enp-3 with plumose inner seta, two setae distally and spine at outer distal corner, both enp-2 and enp-3 outer margin ornamented with spinules.

P3 (Fig. 4A). Basis with bare outer seta. Exp-1 with plumose inner seta, proximal inner margin ornamented with setules, exp-2 with plumose inner seta at distal margin, both exp-1 and exp-2 setules on inner distal margin and outer margin ornamented with spinules; exp-3 with plumose inner seta, long plumose seta at inner terminal, long seta with plumose inner side and pinnate outer side at outer terminal and three outer pinnate spines, proximal outer margin ornamented with spinules. Endopod about as long as exopod, both enp-1 and enp- 2 with plumose inner seta and setules on inner distal margin, enp-3 with two plumose and unipinnate seta on inner side, two setae distally and spine at outer distal corner, outer margin of endopod segments ornamented with spinules.

P4 (Fig. 4B). Basis with bare outer seta. Both exp-1 and exp-2 with plumose inner seta, inner margin ornamented with setules, setules on inner distal margin and outer margin ornamented with spinules; exp-3 with three plumose inner setae, the second seta of three inner setae thicker than others, long plumose seta at inner terminal, long seta with plumose inner side and pinnate outer side at outer terminal and three outer spines, proximal outer margin ornamented with spinules. Endopod longer than exp-1 and exp-2 combined, both enp-1 and enp-2 with plumose inner seta and setules on inner distal margin, enp-3 with two plumose inner setae, two setae distally and spine at outer distal corner, outer margin of endopod segments ornamented with spinules.

P5 (Figs. 5A, 6A). Benp and exopod distinct, benp with long, slender and bare outer basal seta; endopodal lobe bearing three inner bipinnate spines and two bipinnate distal setae. Exopod oval, elongated, 1.7 times longer than wide, with spinules along both inner and outer margins. Exopod bearing bipinnate inner seta, two apical bare setae, three bipinnate outer setae and short bare seta.

Genital area as in Fig. 5B. P6 with long bipinnate seta, unipinnate seta, and short spiniform seta; kidney-shaped seminal receptacle (arrowed in Fig. 5B). Genital double-somite (Fig. 6A) with rows of spinules on ventrolateral surface.

Description of male. - Body (Fig. 1C). About $484.8 \mu \mathrm{m}(\mathrm{n}=3)$ in length, smaller and slenderer than female. First and second abdominal somites each with spinule row near distoventral margins. Sexual dimorphism seen in A1, P1, P2, P5, and P6.

Antennule (Figs. 2A, B). Subchirocer, 10-segmented; armature formula: 1-[1 bare], 2-[8 bare +2 pinnate], 3-[1 bare], 4-[5 bare], 5-[6 bare + ae], 6-[1 bare], 7-[1 bare], 8-[1 bare], 9-[3 bare], 10-[7 bare + ae].

P1 basis (Fig. 3C). With inner spiniform projection.

P2 endopod (Fig. 3D). Two-segmented; enp-1 with inner pinnate seta; enp-2 modified, bearing three inner setae, unipinnate seta distally, and two spiniform setae at mid-length of outer margin. P5 (Figs. 5C, 6C, 6D). Benp and exopod distinct; endopodal lobe ornamented with spinules at inner and outer margin, armatured with two bipinnate spines. Inner spine twice as long as outer 
246

247

248

249

250

251

252

253

254

255

256

257

258

259

260

261

262

263

264

265

266

267

268

269

270

271

272

273

274

275

276

277

278

279

280

281

282

283

284

one. Exopod with five setae in total, including two inner setae, bare long distal seta and two pinnate outer setae, outer margin ornamented with rows of three spines.

P6 (Fig. 5C). Represented by pinnate inner seta and two bare setae on outer distal corner of genital operculum.

Etymology. - The species name refers the type locality of the new species, namely Hawaii. Molecular results. - DNA was extracted and the 18S and mtCOI fragments were successfully PCR-amplified from two specimens and one specimen of the new species, respectively (18S; 1647 bp, 1692 bp, mtCOI; 678 bp). In addition, 18S and mtCOI fragments were PCR-amplified from four specimens and two specimens of $S$. kawamurai, respectively. BLAST analyses of GenBank revealed that the obtained sequences were harpacticoid in origin and not contaminants. All analyses were run with all additional seven miraciid $18 \mathrm{~S}$ sequences and $34 \mathrm{mtCOI}$ sequences downloaded from GenBank (Table 2).

For the $18 \mathrm{~S}$ analysis, sequences from species in eight different genera were obtained from the NCBI database: Amonardia Lang, 1944, Amphiascoides Nicholls, 1941, Diosaccus Boeck, 1873, Miracia Dana, 1846, Paramphiascella Lang, 1944, Stenhelia Boeck, 1865, Typhlamphiascus Lang, 1944, and Sarsamphiascus. Two thalestrid-morpha species, Thalestridae sp., Dactylopusia pauciarticulata, were selected as outgroups for $18 \mathrm{~S}$ analysis. Average pairwise distance between the 13 miraciid sequences was 0.054. The pairwise distance between Sarsamphiascus and Paramphiascella $18 \mathrm{~S}$ sequences was 0.022 . This was the lowest value among the mean distances between Sarsamphiascus and the other seven genera (Table S1). Mean distance within Sarsamphiascus was 0.002. While the neighbor joining tree (Fig. S1) and maximum likelihood tree (Fig. 7A) had the same topology, the Bayesian inference tree (Fig. 7B) topology was different within Amonardia and Stenhelia.

In the mtCOI analysis, within Sarsamphiascus, the pairwise distance between the new species and $S$. undosus was $23.9 \%$, and between the new species and $S$. kawamurai (two specimens) was $24.1 \%$ and $25.8 \%$, respectively (Table S2). These divergence values are within the range of mean distances within other miraciid genera $(5.5$ - 34\%; overall mean distance: $31.5 \%)$ (Table 4).

\section{Discussion}

The new species described here clearly belongs to the genus Sarsamphiascus based on the presence of several diagnostic characters for the genus including P1 enp-1 longer than exp, P1 exp-3 with five setae, every exp-1, 2 with inner seta, P2 enp-2 with two inner setae, P3 enp-3 with three inner setae, and $\mathrm{P} 4$ enp shorter than exp. Within this genus, the pacificus-group has the following common characters: A2 exp-1 with seta and P1 exp-2 without inner seta.

The type species of this genus is $S$. minutus (Claus, 1863), originally reported as Dactylopus minutus from Helgoland, Germany. Conspicuous morphological differences between the type species and $S$. hawaiiensis sp. nov. are the presence of seta on A2 exp-2 and P1 exp-2, the length of P1 exp-2 and enp-3 segments, and the number of seta on P3 enp-2. A comparison of other morphological features is provided in Table 1. 
285

286

287

288

289

290

291

292

293

294

295

296

297

298

299

300

301

302

303

304

305

306

307

308

309

310

311

312

313

314

315

316

317

318

319

320

321

322

323

324

Based on previous descriptions and keys to harpacticoid species (Lang 1948; Wells 2007), S. hawaiiensis is superficially similar to Sarsamphiascus kawamurai (Ueda \& Nagai, 2005). This latter species was reported from outdoor laver cultivation tanks on the shore of Ariake Bay, Kyushu, Japan by Ueda and Nagai (2005); tidal pool and salt marshes in the East Sea, Korea by Chang (2009); and sublittoral rocks in the Aegean Sea and Mediterranean Sea of Turkey by Sönmez et al. (2014). According to the descriptions in the three reports mentioned above, the distinguishable characters of $S$. kawamurai are the absence of a ventral row of spinules on the genital double-somite, bare caudal terminal setae, pinnate seta on the first segment of A1, and short outer seta of the male P5 baseoendopod. S. hawaiiensis and S. kawamurai share the characters of setal formula, elongated P5 exp, and presence of an inner margin with spinules on the P5 exp. However, the new species and S. kawamurai can be distinguished by the combination of the following morphological characteristics: (1) elongated segments of the antennule in the new species, especially the second and third segments of the antennule (twice as long as broad) (1.4 and 1.3 times in S. kawamurai, respectively); (2) type of outer setae of the P5 exopod (bare in S. kawamurai); (3) position of the inner seta of the P5 exopod in both sexes (more proximal in S. kawamurai); (4) length and type of the setae of female P6 (shorter and bare in S. kawamurai). This new species is the first report of the genus Sarsamphiascus in the Hawaiian Islands.

The new species and $S$. undosus share the characters of setal formula, short innermost seta of female P5 benp, and caudal rami terminal setae with ornamentation. However, the new species and $S$. undosus can be distinguished from each other by the combination of the following morphological characteristics: (1) ratio of length and width of female P5 exp (round in $S$. undosus); (2) length of outer setae of female P5 exp (longer in S. undosus); (3) type of two inner setae onP6 (bare in S. undosus); (4) seta type of the A1 second segment (bare in S. undosus); (5) type of inner edge of caudalterminal seta (undulate in the proximal part in $S$. undosus).

When these three species with similar morphologies were compared within the pacificus-group, ratios of the length to width of the rostrum, A1 segments, P5 exp, and caudal rami of the new species were found to be higher than those of the other two congeners: the ratio of rostrum length to width is 2.8 (vs. 2 in $S$. kawamurai and $S$. undosus); the ratio of the length to width of the second and third antennular segment is 2 (1.3-1.4 in S. kawamurai and S. undosus); the ratio of the length to width of the female P5 exp is 1.7 (1.65 in S. kawamurai and 1.3 in S. undosus); and the ratio of the length to width of the caudal rami is 0.75 (0.6 in $S$. kawamurai and 0.64 in $S$. undosus).

In addition, ornamentations of setae vary between these species. The new species has more ornamented setae on the second antennular segment, maxilliped, and P6. The new species also has ornamented setae on the second antennular segment and distal part of maxilliped. The two setae of P6 are pinnate (all bare in S. kawamurai and S. undosus).

All these characters suggest that the new species might have diverged early in the evolution of the pacificus-group compared with the congener species (S. kawamurai and S. undosus).

Comparison of the four species groups within Sarsamphiascus revealed that there are two inner setae on P3 enp-2 in the minutus-group versus seta in the other groups. The minutus-group and 
325

326

327

328

329

330

331

332

333

334

335

336

337

338

339

340

341

342

343

344

345

346

347

348

349

350

351

352

353

354

355

356

357

358

359

360

361

362

363

364

varians-group have inner seta on P1 exp-2 (absent in pacificus-group and amblyops-group). Sarsamphiascus amblyops (Sars G.O., 1911) in the amblyops-group exceptively has two setae on A2 exp-1 (seta in other groups). These reductions in swimming leg setation and A2 exp suggest that the minutus-group is the most primitive group within the genus followed by the variansgroup. The pacificus-group is the most advanced group based on these characters. To evaluate if these morphological characters are homologous, more molecular data for the four species groups within this genus are required.

Analysis of $18 \mathrm{~S}$ and $\mathrm{mtCOI}$ sequences revealed that the genera most closely related to Sarsamphiascus are Paramphiascella (0.022; Table S1) and Eoschizopera (0.257; Table S3). Since the types of molecular marker registered in NCBI differ by species, more DNA barcodes studies are necessary to establish a database for accurate comparison.

Since the genus Amphiascus has undergone many systematic changes, there are still several lineages that need to be studied using molecular data. The sequence information generated in this study is likely to be useful in future studies.

Three different methods were used to obtain phylogenetic trees based on the $18 \mathrm{~S}$ data. While the neighbor-joining tree (Fig. S1) and maximum likelihood tree (Fig. 7A) had the same topology, the Bayesian inference tree (Fig. 7B) was different. In the Bayesian inference tree, Amonardia was more closely related to Stenhelia sp. than in the other trees. It is difficult to determine which result is more reasonable because bootstrap values for the clade containing Amonardia did not exceed 0.6 in any of the trees. However, support for the grouping of Amonardia with Miracia and Diosaccus was slightly higher as the NJ tree and ML tree. Nevertheless, common findings in all three trees were that all Sarsamphiascus species formed a monophyletic group and that Sarsamphiascus formed a clade with other Diosaccinae species with high probability. Furthermore, Diosaccus and Amonardia formed a clade with Miracia and Stenhelia, separated from subfamily Diosaccinae. The systematic positions of the three subfamilies relative to each other need to be redefined through analyses that include more miraciid sequences.

Pairwise distance results for the mtCOI gene support the distinctness of $S$. hawaiiensis sp. nov. from S. undosus and S. kawamurai and support that these species belong to the same genus based on the range of pairwise distance values seen in other genera within the family Miraciidae (Table 4).

Key to species of the genus Sarsamphiascus (modified from Lang 1948 and Wells 2007)

We developed an updated key based on selected characteristics from the original description that identify species within the genus Sarsamphiascus.

\section{P3 enp-2 with inner seta ... 2}

- P3 enp-2 with two inner setae ... $4<$ Minutus Group $>$

2. P1 exp-2 with inner seta ... $15<$ Varians Group $>$ 
365 - P1 exp-2 without inner seta ... 3

366 3. A2 exp-1 with seta ... $26<$ Pacificus Group $>$

367 - A2 exp-1 with two setae ... S. amblyops (Sars G.O., 1911) <Amblyops Group >

368 4. P2 exp-3 with two outer spines ... S. demersus (Nicholls, 1939)

369 - P2 exp-3 with three outer spines ... 5

370 5. Exp-3 of P3-P4 with eight setae; A2 exp-2 with seta ... 6

371 - These characters not combined. ... 7

372 6. Ratio of the length of P1 enp-3 to enp-2 is 3 ... S. longiarticulatus (Marcus, 1974)

373 - Ratio of length of P1 enp-3 to enp-2 is 1.5 ... S. paracaudaespinosus (Roe, 1958)

374 7. P3 enp-2 with two inner setae; A2 exp-2 without seta or A2 exp two-segmented ... 8

375 - These characters not combined. ... 9

376 8. A2 exp two or three-segmented; P3 exp-3 with seven setae; P4 exp-3 with eight setae; rostrum

377 triangular and apex extremely finely pointed; P1 enp-3 length at least twice as long as enp-2

378 length ... S. ultimus (Monard, 1928)

379 - A2 exp two or three-segmented; P3 exp-3 with seven setae; P4 exp-3 with eight setae; female,

380 caudal rami longer than breadth with a dorsal ridge/ male, caudal rami much broader than length;

381 P5 exp with five setae; length of P1 enp-2 and enp-3 approximately equal ... S. discrepans

382 (Mielke, 1989)

383 - A2 exp three-segmented; P3 exp-3 with eight setae (if seven setae, caudal rami approximately

384 as broad as long and length of $\mathrm{P} 1$ enp-2 and enp-3 approximately equal) ... S. caudaespinosus

385 (Brian, 1927)

386 - These characters not combined. ... 9

387 9. P1 exp-2 normal, not extended ... 10

388 - P1 exp-2 extended ... 13

389 10. P5 exp of female with seven setae ... S. brevis (Sars G.O., 1909)

390 - P5 exp of female with seven setae ... 11

391 11. Ratio of P1 enp-1 length to breadth is 5; P5 benp, outer distal corner round in both sexes; P5

392 exp of male with six setae ... S. congener (Sars G.O., 1909)

393 - Ratio of P1 enp-1 length to breadth is 6 or more ... 12

394 12. Female, outer distal corner of P5 benp round / male, outer distal corner of P5 benp square ...

395 S. graciloides (Klie, 1950)

396 - Outer distal corner of P5 benp square in both sexes ... S. tenuiremis (Brady, 1880)

397 13. P5 benp of female with four well-developed setae and short seta. .. 14

398 - P5 benp of female with five well-developed setae ... S. minutus (Claus, 1863)

399 14. P5 exp of female with tapering distal edge ... S. hirtus (Gurney, 1927)

400 - P5 exp of female round ... S. gracilis (Lang, 1936)

401 15. P4 exp-3 with seven setae ... S. ampullifer (Humes, 1953)

402 - P4 exp-3 with eight setae ... 16

403 16. P5 exp of female with five setae ... S. varians (Norman \& Scott T., 1905)

404 - P5 exp of female with six setae ... 17 
405 17. P5 benp of female, seta I and II widely apart ... 18

406 - P5 benp of female, seta I and II not widely apart ... 19

407 18. First segment of A1 with spur ... S. dentiformis (Coull, 1971)

408 - First segment of A1 without spur ... S. gauthieri (Monard, 1936)

409 19. P5 benp of female does not extend beyond half the length of the P5 exp ... 20

410 - P5 benp of female extends beyond half the length of the P5 exp ... 22

411 20. P5 benp of female does not reach half the length of the P5 exp ... S. angustipes (Gurney,

412 1927)

413 - P5 benp of female reaches half the length of the P5 exp ... 21

414 21. P5 exp of female at least twice as long as broad ... S. propinquus (Sars G.O., 1906)

415 - P5 exp of female not twice as long as broad ... S. polaris (Sars G.O., 1909)

416 22. P5 benp of female reaches to the end of the P5 exp ... S. elongatus (Itô, 1972)

417 - P5 benp of female does not reach the end of the P5 exp ... 23

418 23. P1 enp-3 outer margin with spinules ... 24

419 - P1 enp-3 outer margin without spinules ... S. profundus (Becker \& Schriever, 1979)

420 24. P5 benp of male with three setae and outer distal corner of benp with an obvious spiniform

421 seta ... S. tenellus (Sars G.O., 1906)

422 - P5 benp of male with two setae and outer distal corner of benp with a mucroniform projection

$423 \quad \ldots 25$

424 25. P1 enp-2 and enp-3 with bare seta ... S. tainui (Hicks, 1989)

425 - P1 enp-2 and enp-3 with pinnate seta ... S. lobatus (Hicks, 1971)

426 26. P2-P3 exp-1 with inner seta ... 27

427 - P2-P3 exp-1 without inner seta ... S. humphriesi (Roe, 1960)

428 27. A2 exp-2 with seta; P5 benp without hyaline fields ... 28

429 - A2 exp-2 without seta ... 29

430 28. A2 exp-3 with inner seta; P2-P4 enp extending to at least the end of the exp; P5 exp of

431 female oval ... S. sinuatus (Sars G.O., 1906)

432 - A2 exp-3 without inner seta; P2-P4 enp does not extend to at least the end of the exp; P5 exp of

433 female tapers ... S. pacificus (Sars G.O., 1905)

434 29. P5 exp of female round; inner terminal seta of caudal rami undulating in proximal part of

435 inner edge ... S. undosus (Lang, 1965)

436 - P5 exp of female oval; inner terminal seta of caudal rami straight ... 30

437 30. P5 exp of female, both third and fourth setae from inside long and extend well beyond exp ...

$438 \quad 31$

439 -P5 exp of female, third seta from inside extend well beyond exp; fourth seta extends only to

440 about the end of $\exp \ldots$... S. hawaiiensis sp. nov.

441 31. A1 with pinnate seta on first segment; male P5 benp outer seta shorter than half the length of

442 the inner seta ... S. kawamurai (Ueda \& Nagai, 2005)

443 - A1 without pinnate seta, all bare setae; male P5 benp outer seta as long as inner seta ... $S$.

444 parvus (Sars G.O., 1906) 
445

446

447

448

449

450

451

452

453

454

455

456

457

458

459

460

461

462

463

464

465

466

467

468

469

470

471

472

473

474

475

476

477

478

479

480

481

482

483

484

\section{Conclusions}

A new species, $S$. hawaiiensis sp. nov., was collected from subtidal sandy sediments of Hawaii. The new species can be distinguished from its congeners in the pacificus-group by morphological characteristics and molecular analyses of mtCOI genes and 18S rRNA genes. This is the first species of Sarsamphiascus to be discovered from Hawaii.

In this genus, molecular data for only one of four species groups (the pacificus-group) is currently available in NCBI. To evaluate whether genus designations based on morphological characters are correct and to determine phylogenetic relationships among genera, more molecular data for the four groups need to be generated and analyzed.

Since the genus Sarsamphiascus has undergone many systematic changes, and because morphological differences between species are miniscule, further molecular studies are necessary to distinguish the evolutionary position of the new species within Sarsamphiascus.

\section{Acknowledgements}

We would like to thank the Marine Zooplankton Resources Bank of Korea for providing specimens of S. kawamurai and Raehyuk Jeong for reading and revising the manuscript. We express our sincere gratitude to editor Prof. James Reimer, reviewer Prof. Viatcheslav Ivanenko, and two anonymous reviewers for their constructive comments and advice on the earlier version of the manuscript.

\section{References}

Boxshall GA, Halsey SH. 2004. An Introduction to Copepod Diversity. The Ray Society, London, 966pp.

Bucklin A, Ortman BD, Jennings RM, Nigro LM, Sweetman CJ, Copley NJ, Sutton T, Wiebe PH. 2010. A "Rosetta Stone" for metazoan zooplankton: DNA barcode analysis of species diversity of the Sargasso Sea (Northwest Atlantic Ocean). Deep Sea Research Part II: Topical Studies in Oceanography 57(24-26):2234-2247.

Chang CY. 2009. Three miraciid copepods (Harpacticoida, Miraciidae) from South Korea. Animal Systematics, Evolution and Diversity 25(3):215-225.

Chullasorn S, Anansatitporn W, Kangtia P, Klangsin P, Jullawateelert R. 2011. Review of Naupliar Development among Miraciidae (Copepoda, Harpacticoida) with a Naupliar Description of Paramphiascella choi sp. nov. from Thailand. Hydrobiologia 666:21-43.

Eberl R, Carpenter EJ. 2007. Association of the copepod Macrosetella gracilis with the cyanobacterium Trichodesmium spp. in the North Pacific Gyre. Marine Ecology Progress Series 333:205-212.

Easton EE, Darrow EM, Spears T, Thistle D. 2014. The mitochondrial genomes of Amphiascoides atopus and Schizopera knabeni (Harpacticoida: Miraciidae) reveal similarities between the copepod orders Harpacticoida and Poecilostomatoida. Gene 538(1): $123-137$. 
485

486

487

488

489

490

491

492

493

494

495

496

497

498

499

500

501

502

503

504

505

506

507

508

509

510

511

512

513

514

515

516

517

518

519

520

521

522

523

524

Gollner S, Stuckas H, Kihara TC, Laurent S, Kodami S, Arbizu PM. 2016. Mitochondrial DNA analyses indicate high diversity, expansive population growth and high genetic connectivity of vent copepods (Dirivultidae) across different oceans. PloS one 11(10):e0163776.

Hicks GRF. 1989. Harpacticoid copepods from biogenic substrata in offshore waters of New Zealand: Partial revisions of Dactylopodella Sars and Amphiascus Sars (varians-group) including new species, and a new record for Harrietella simulans (T. Scott). Records of the National Museum of New Zealand 3:101-117.

Huys R, Mu FH. 2008. Description of a new species of Onychostenhelia Itô (Copepoda, Harpacticoida, Miraciidae) from the Bohai Sea, China. Zootaxa 1706:51-68.

Huys R, Gee JM, Moore CG, Hamond R. 1996. Marine and brackish water harpacticoid copepods part 1- Synopses of the British Fauna (New Series). (Eds R.S.K.Barnes and J.H.Crothers) 51, 352pp.

Huys R. 2009. Unresolved cases of type fixation, synonymy and homonymy in harpacticoid copepod nomenclature (Crustacea: Copepoda). Zootaxa 2183:1-99.

Huys R, Mackenzie-Dodds J, Llewellyn-Hughes J. 2009. Cancrincolidae (Copepoda, Harpacticoida) associated with land crabs: a semiterrestrial leaf of the ameirid tree. Molecular Phylogenetics and Evolution 51(2):143-156 DOI 10.1016/j.ympev.2008.12.007. Karanovic T, Cooper SJB. 2012. Explosive Radiation of the Genus Schizopera on A Small Subterranean Island in Western Australia (Copepoda: Harpacticoida): Unravelling the Cases of Cryptic Speciation, Size Differentiation and Multiple Invasions. Invertebrate Systematics 26(2):115-192.

Karanovic T, Kim K, Lee W. 2014. Morphological and molecular affinities of two East Asian species of Stenhelia (Crustacea, Copepoda, Harpacticoida). ZooKeys 411:105.

Kimura M. 1980. A simple method for estimating evolutionary rates of base substitutions through comparative studies of nucleotide sequences. Journal of molecular evolution 16(2):111-120.

Khodami S, McArthur JV, Blanco-Bercial L, Martinez Arbizu P. 2017. Molecular phylogeny and revision of copepod orders (Crustacea: Copepoda). Scientific Reports 7(1):1-11 DOI 10.1038/s41598-017-06656-4.

Kumar S, Stecher G, Tamura K. 2016. MEGA7: molecular evolutionary genetics analysis version 7.0 for bigger datasets. Molecular biology and evolution 33(7):1870-1874.

Kunz H. 1995. Schizopera hawaiiensis sp. n. (Copepoda, Harpacticoida) aus einer Lagune auf Oahu, Hawaii-Inseln. Mitteilungen aus dem Hamburgischen Zoologischen Museum und Institut, Hamburg 92:65-72.

Lang K. 1948. Monographie der harpacticiden. Håkan Ohlsson. Lund 2 vols, 1682 pp.

Lang K. 1965. Copepoda Harpacticoidea from the Californian Pacific coast. Kunglieren svenska Vetenskapsakademiens Handlingar 10(2):1-560.

Nei M, Kumar S. 2000. Molecular evolution and phylogenetics. Oxford university press.

Rossel, S., \& Arbizu, P. M. (2019). Revealing higher than expected diversity of Harpacticoida (Crustacea: Copepoda) in the North Sea using MALDI-TOF MS and molecular barcoding.

Peer) reviewing PDF | (2019:06:38481:1:1:NEW 1 Jan 2020) 
525

526

527

528

529

530

531

532

533

534

535

536

537

538

539

540

541

542

543

544

545

546

547

548

549

Scientific Reports 9(1): 9182.

Song SJ, Rho HS, Kim W. 2007. A New Species of Amonardia (Copepoda: Harpacticoida: Miraciidae) from the Cultivated Brown Alga, Undaria pinnatifida. Integrative Biosciences 11(1):69-77.

Sönmez S, Sak S, Karaytuğ S. 2014. Marine interstitial and phytal Miraciidae Dana, 1846 (Crustacea: Copepoda: Harpacticoida) inhabiting along the mediolittoral zone of Turkish coasts. Journal of Anatolian Natural Sciences 5:52-96.

Thompson JD, Higgins DG, Gibson TJ. 1994. CLUSTAL W: improving the sensitivity of progressive multiple sequence alignment through sequence weighting, position-specific gap penalties and weight matrix choice. Nucleic acids research 22(22):4673-4680.

Ueda H, Nagai H. 2005. Amphiascus kawamurai, a new harpacticoid copepod (Crustacea: Harpacticoida: Miraciidae) from nori cultivation tanks in Japan, with a redescription of the closely related $A$. parvus. Species diversity: an international journal for taxonomy, systematics, speciation, biogeography, and life history research of animals 10(4):249-258.

Wells JBJ. 2007. An Annotated Checklist and Keys to the Species of Copepoda Harpacticoida (Crustacea). Zootaxa 1568:1-872.

Willen E. 2002. Notes on the Systematic Position of the Stenheliinae (Copepoda, Harpacticoida) within the Thalestridimorpha and Description of Two New Species from Motupore Island, Papua New Guinea. Cahiers de Biologie Marine 43:27-42.

Williams BD, Schrank B, Huynh C, Shownkeen R, Waterston RH. 1992. A genetic mapping system in Caenorhabditis elegans based on polymorphic sequence-tagged sites. Genetics 131(3):609-624.

Yamaguchi S, Endo K. 2003. Molecular phylogeny of Ostracoda (Crustacea) inferred from 18S ribosomal DNA sequences: implication for its origin and diversification. Marine Biology 143(1):23-38. 
Figure 1

Sarsamphiascus hawaiiensis sp. nov.

(A) Habitus of female, dorsal. (B) Habitus of female, lateral. (C) Habitus of male, dorsal. (D) Caudal ramus of female, ventral. Scale bars: $50 \mu \mathrm{m}$ (A - C), $20 \mu \mathrm{m}$ (D). 


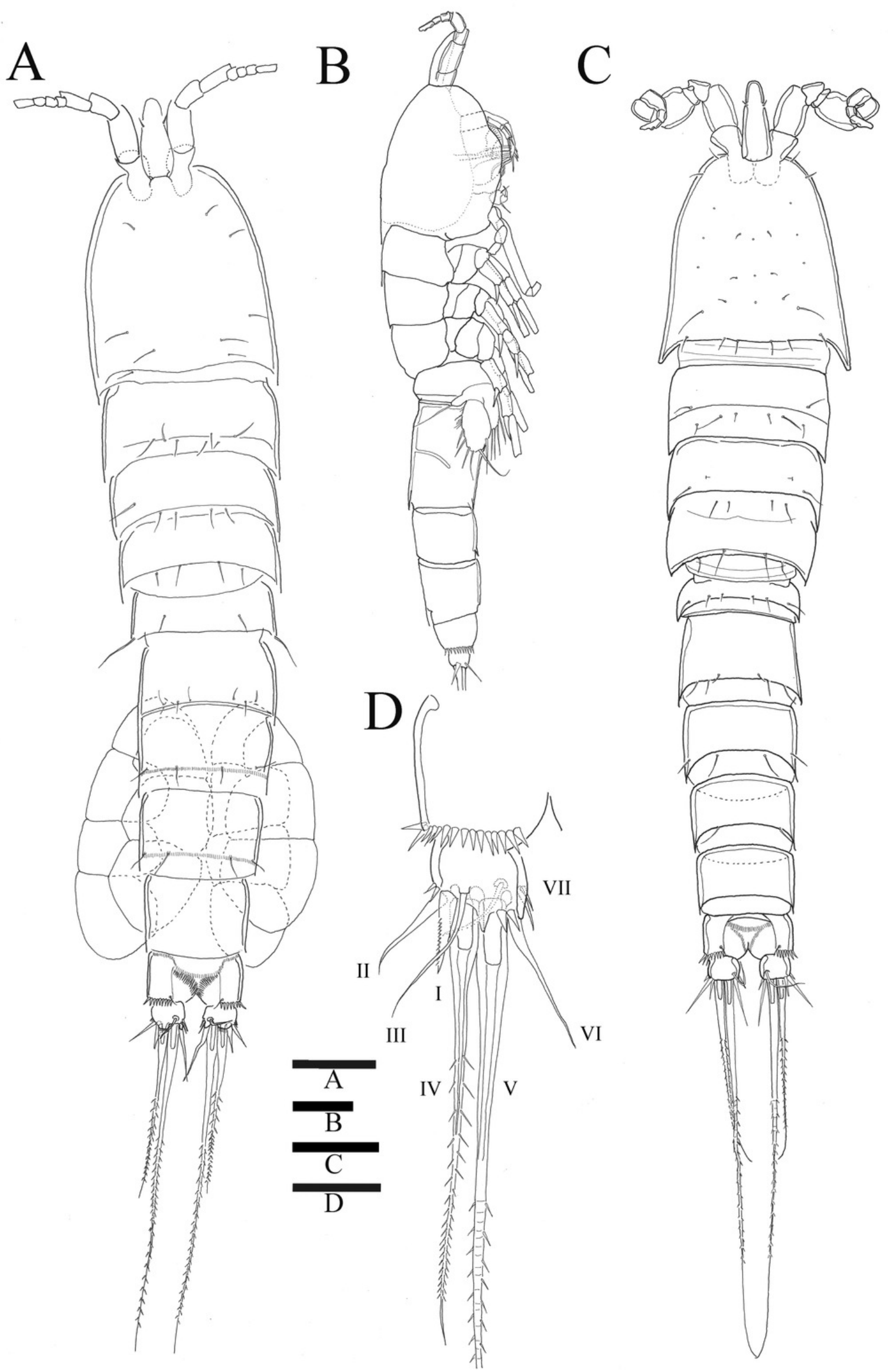


Figure 2

Sarsamphiascus hawaiiensis sp. nov.

A - B, Male: (A) Segments of A1. (B) Antennule and Rostrum. C - H, Female: (C) Antennule and Rostrum. (D) Antenna. (E) Mandible. (F) Maxillule. (G) Maxilla. (H) Maxilliped. Scale bars: $10 \mu \mathrm{m}$. 

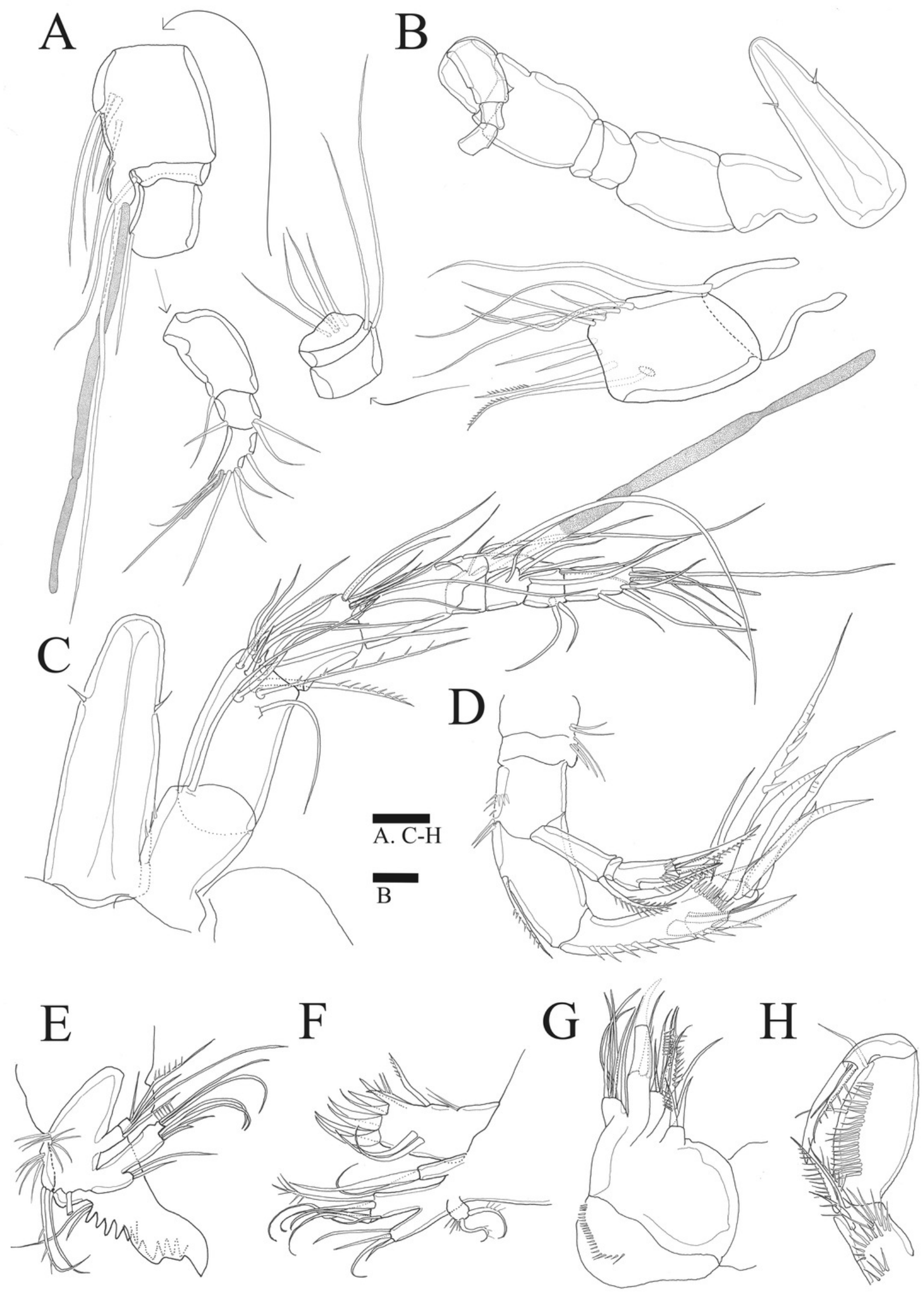
Figure 3

Sarsamphiascus hawaiiensis sp. nov.

A - B, Female: (A) P1. (B) P2. C - D, Male: (C) P2 endopod. (D) P1 basis. Scale bar: $20 \mu \mathrm{m}$. 


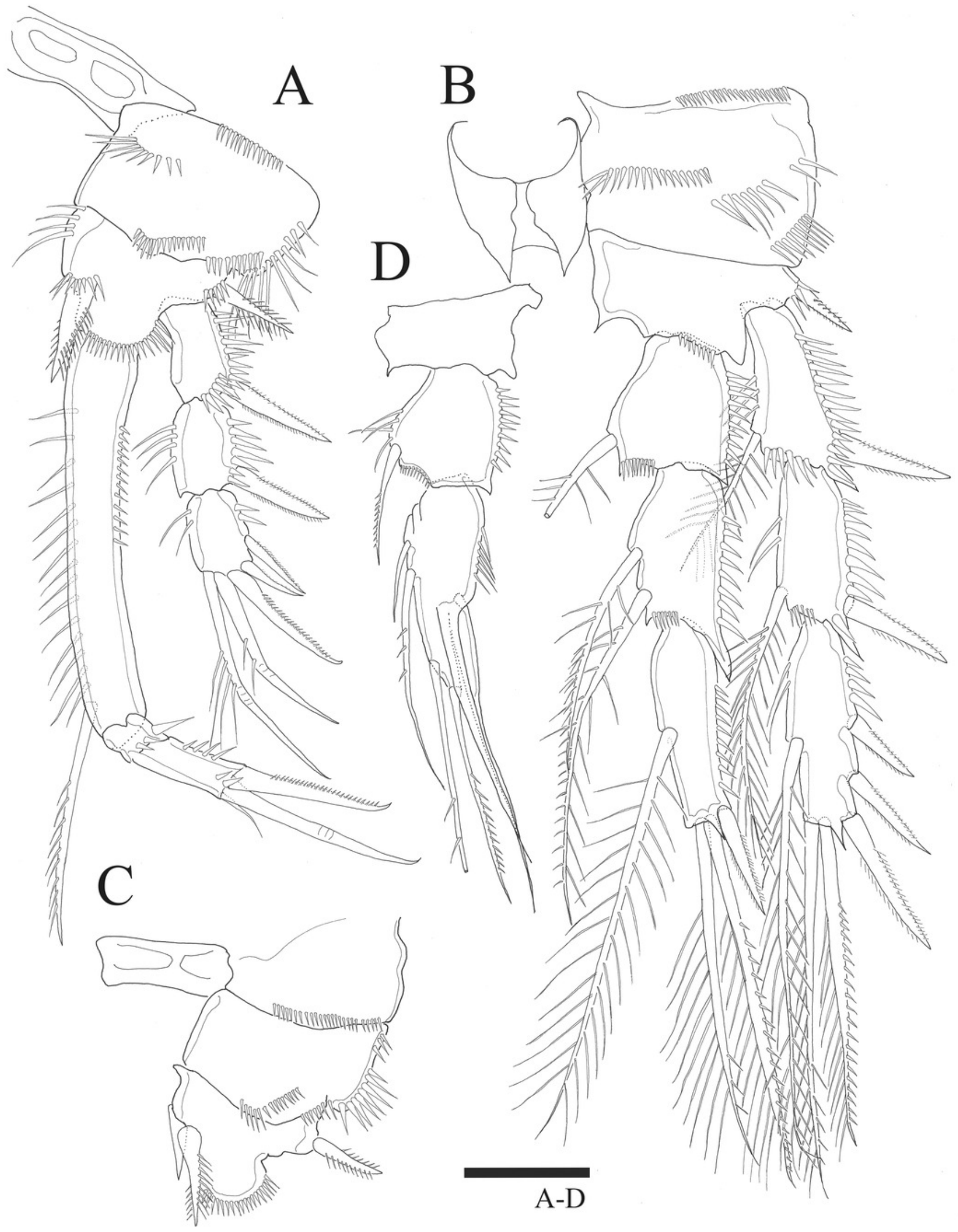


Figure 4

Sarsamphiascus hawaiiensis sp. nov.

Female: (A) P3. (B) P4. Scale bar: $20 \mu \mathrm{m}$. 


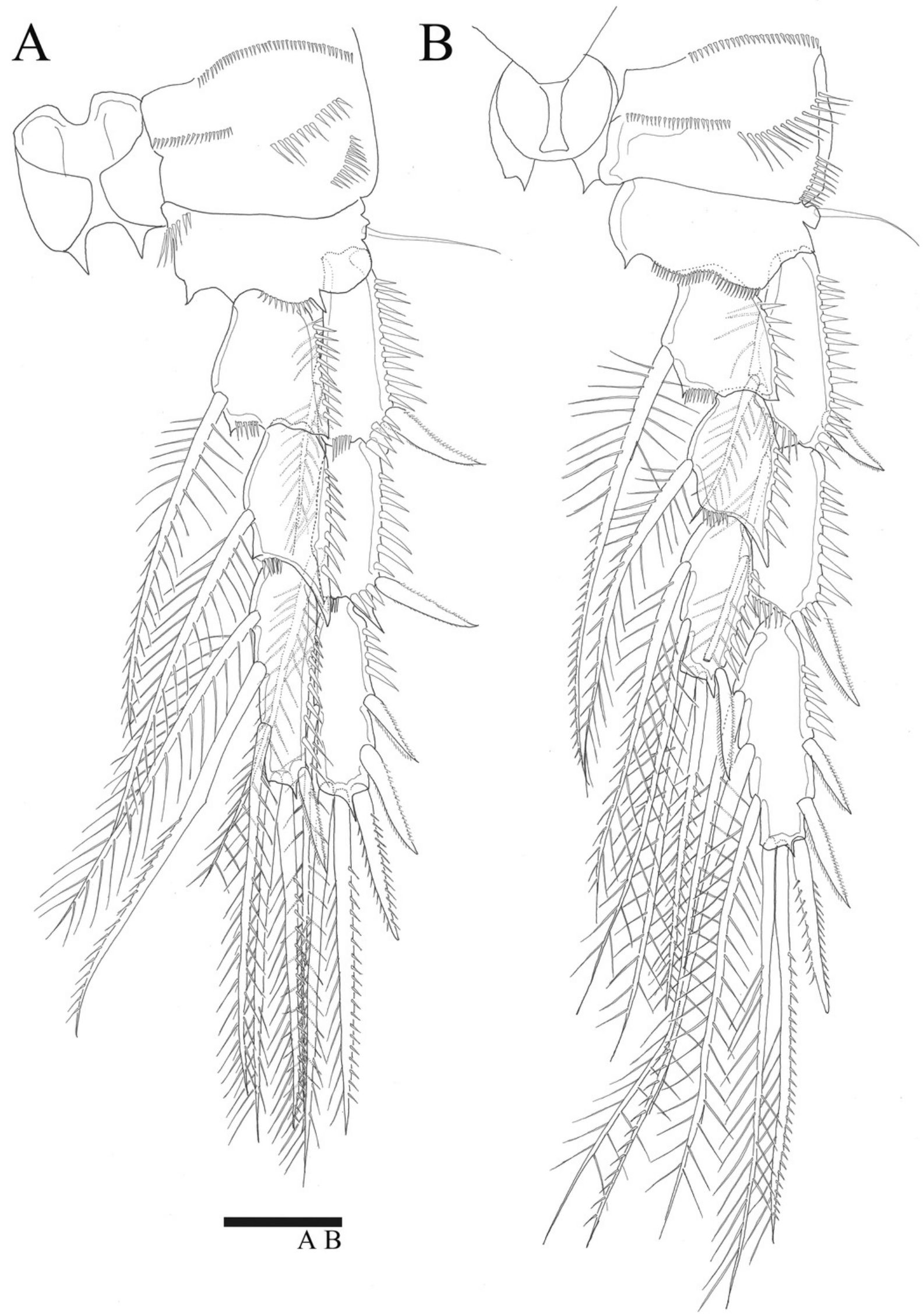


Figure 5

Sarsamphiascus hawaiiensis sp. nov.

A - B, Female: (A) P5. (B) Genital field. C, Male: (C) P5, P6, and urosome (right), ventral. Scale bar: $20 \mu \mathrm{m}$.
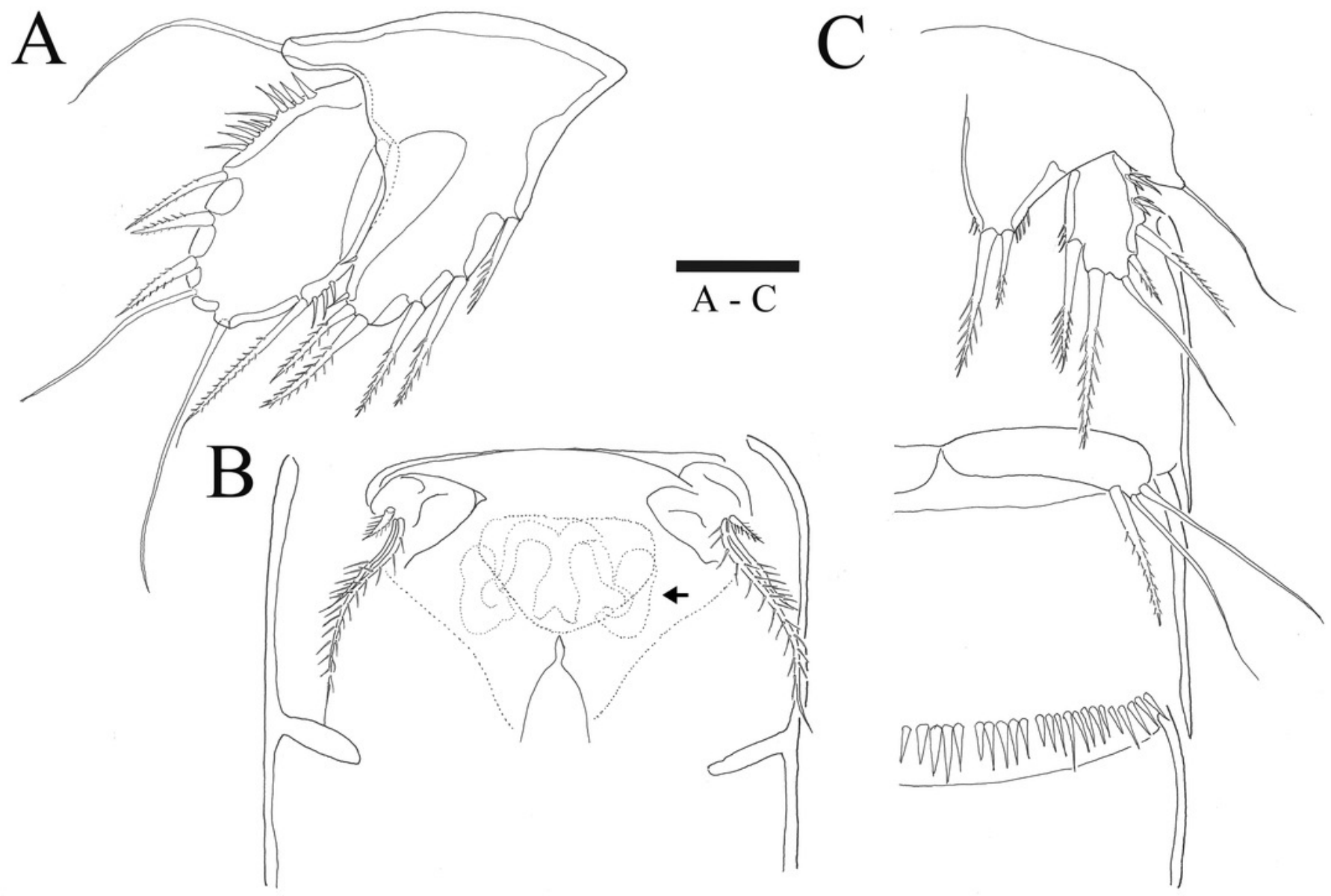
Figure 6

Sarsamphiascus hawaiiensis sp. nov., SEM photographs.

Female: (A) Genital double-somite and P5, lateral. Male: (B) A2 exp. (C) P5. (D) Rows of 3 spines on outer margin of P5. (E) Anal somite and Caudal rami, dorsal. (F) Caudal ramus, dorsal. 


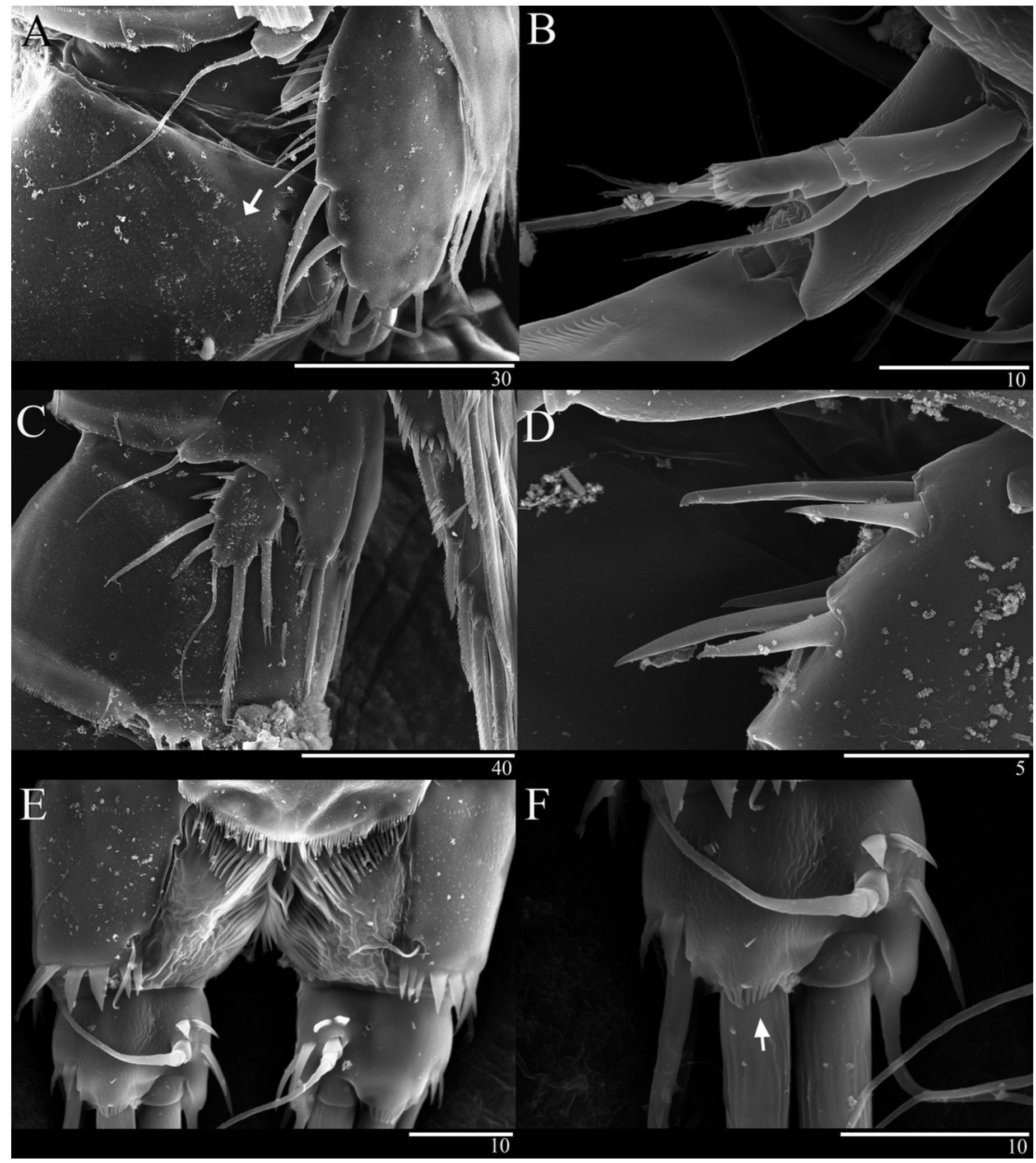


Figure 7

Phylogenetic trees of Miraciidae based on nuclear 18S ribosomal RNA data.

(A) Maximum Likelihood [ML] phylogenetic tree. (B) Bayesian Inference [BI] phylogenetic tree. 


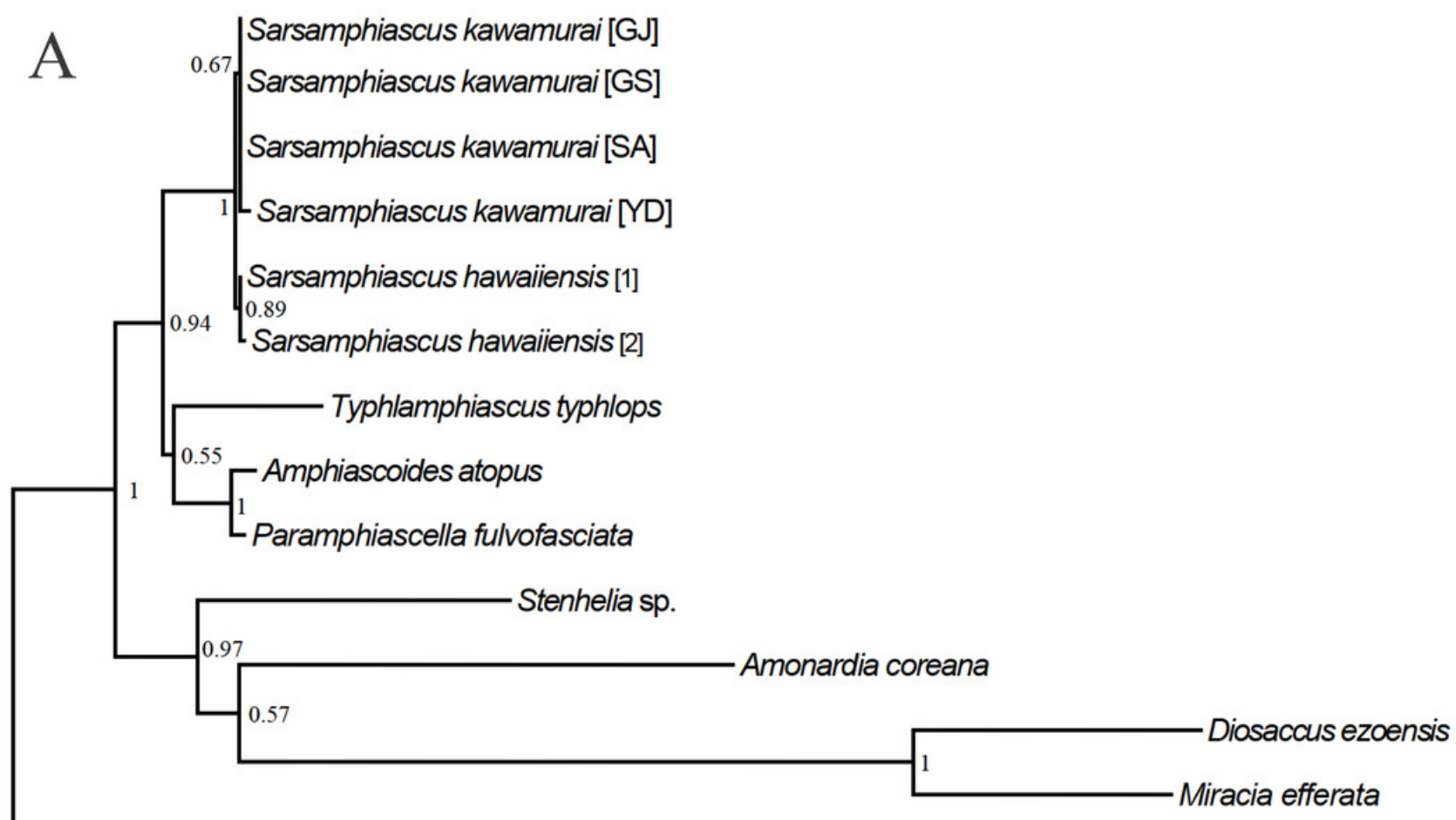

-Thalestridae sp.

Dactylopusia pauciarticulata

0.02

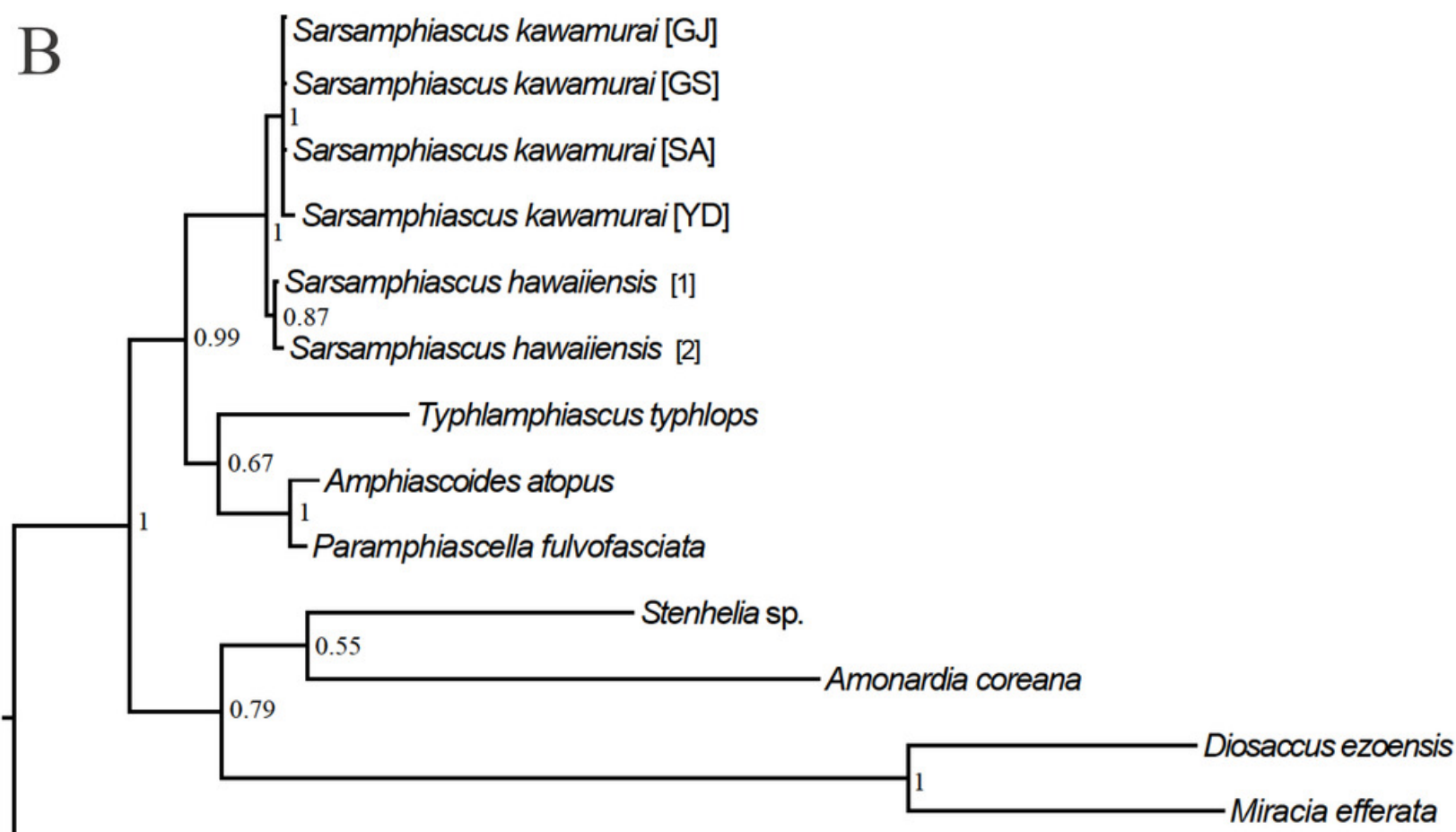

Thalestridae sp

Dactylopusia pauciarticulata 


\section{Table $\mathbf{1}$ (on next page)}

Comparison of pacificus-group and the type species of the genus.

S. minutus (Claus, 1863) is the type species of the genus (minutus-group); O: seta(e)/ spinule presence; $\mathrm{X}$ : seta(e)/ spinule absence; *mixed: One seta is longer than exp, another is shorter. 
1 Table 1: Comparison of pacificus-group and the type species of the genus.

\begin{tabular}{|c|c|c|c|c|c|c|c|c|c|c|}
\hline Species & Habitat & $\begin{array}{l}\text { The } \\
\text { number of } \\
\text { P3 enp-2 } \\
\text { inner setae }\end{array}$ & $\begin{array}{l}\text { A2 } \\
\text { exp-2 } \\
\text { seta }\end{array}$ & $\begin{array}{l}\text { P5 exp } \\
\text { shape } \\
\text { (length } \\
\text { /breadth) }\end{array}$ & $\begin{array}{l}\text { The } \\
\text { length } \\
\text { of P5 } \\
\text { exp } \\
\text { setae } \\
\left(3^{\text {rd }}, 4^{\text {th }}\right. \\
\text { from } \\
\text { inside })\end{array}$ & $\begin{array}{l}\text { P5 exp } \\
\text { inner } \\
\text { margin } \\
\text { spinules }\end{array}$ & $\begin{array}{l}\text { The } \\
\text { length } \\
\text { of P5 } \\
\text { benp } \\
\text { and } \\
\text { inner- } \\
\text { most } \\
\text { seta }\end{array}$ & $\begin{array}{l}\text { Caudal } \\
\text { rami } \\
\text { seta } \mathrm{V} \\
\text { inner } \\
\text { margin }\end{array}$ & $\begin{array}{l}\text { Caudal } \\
\text { terminal } \\
\text { setae } \\
\text { type }\end{array}$ & $\begin{array}{l}\text { A1 } \\
\text { pinnate } \\
\text { setae } \\
\text { (location) }\end{array}$ \\
\hline S. minutus & $\begin{array}{l}\text { algae, } \\
\text { net sweeping }\end{array}$ & 2 & $\mathrm{O}$ & $\begin{array}{l}\text { oval } \\
(1.43)\end{array}$ & $<\exp$ & $\mathrm{O}$ & >benp & straight & pinnate & $\begin{array}{l}\mathrm{O} \\
(\mathrm{seg}-2)\end{array}$ \\
\hline S. pacificus & $\begin{array}{l}\text { lagoon with } \\
\text { brackish water }\end{array}$ & 1 & $\mathrm{O}$ & $\begin{array}{l}\text { heart } \\
\text { shape } \\
(1.38)\end{array}$ & $<\exp$ & $\mathrm{O}$ & $=$ benp & straight & naked & $\mathrm{X}$ \\
\hline S. sinuatus & $\begin{array}{l}\text { muddy sand } \\
\text { sediment }\end{array}$ & 1 & $\mathrm{O}$ & $\begin{array}{l}\text { oval } \\
(1.52)\end{array}$ & mixed* & $\mathrm{O}$ & $>$ benp & straight & pinnate & $\mathrm{X}$ \\
\hline S. parvus & $\begin{array}{l}\text { coral sand, } \\
\text { subtidal zone } \\
\text { sand }\end{array}$ & 1 & $X$ & $\begin{array}{l}\text { oval } \\
(1.38)\end{array}$ & $>\exp$ & $\mathrm{X}$ & $\geq$ benp & straight & pinnate & $\mathrm{X}$ \\
\hline S. undosus & algae, fine sand & 1 & $\mathrm{X}$ & $\begin{array}{l}\text { round } \\
(1.27)\end{array}$ & $>\exp$ & $\mathrm{O}$ & $<$ benp & $\begin{array}{l}\text { undulat } \\
\text { ing }\end{array}$ & pinnate & $\mathrm{X}$ \\
\hline
\end{tabular}




\begin{tabular}{|c|c|c|c|c|c|c|c|c|c|c|}
\hline S. kawamurai & $\begin{array}{l}\text { tidal pool, } \\
\text { salt marshes, } \\
\text { supralittoral } \\
\text { rocks }\end{array}$ & 1 & $X$ & $\begin{array}{l}\text { oval } \\
(1.65)\end{array}$ & $>\exp$ & $\mathrm{O}$ & $=$ benp & straight & naked & $\begin{array}{l}\mathrm{O} \\
(\operatorname{seg}-1)\end{array}$ \\
\hline S. humphriesi & stone washing & 1 & $\mathrm{O}$ & $\begin{array}{l}\text { oval } \\
(1.5)\end{array}$ & mixed* & $\mathrm{O}$ & $\geq$ benp & straight & - & $\mathrm{X}$ \\
\hline $\begin{array}{l}\text { S. hawaiiensis } \\
\text { (New species) }\end{array}$ & sandy sediment & 1 & $\mathrm{X}$ & $\begin{array}{l}\text { oval } \\
(1.7)\end{array}$ & mixed* & $\mathrm{O}$ & $<$ benp & straight & pinnate & $\begin{array}{l}\mathrm{O} \\
(\mathrm{seg}-2)\end{array}$ \\
\hline
\end{tabular}

2 S. minutus (Claus, 1863) is the type species of the genus (minutus-group); O: seta(e)/ spinule presence; X: seta(e)/ spinule absence;

3 *mixed: One seta is longer than exp, another is shorter. 


\section{Table 2 (on next page)}

GenBank numbers of sequences used in phylogenetic analyses in this study. 
1 Table 2. GenBank numbers of sequences used in phylogenetic analyses in this study.

\begin{tabular}{|c|c|c|c|}
\hline $\begin{array}{l}\text { Gene } \\
\text { marker }\end{array}$ & Species name & $\begin{array}{l}\text { Accession } \\
\text { no. }\end{array}$ & Reference \\
\hline \multirow[t]{15}{*}{$18 \mathrm{~S}$} & Amonardia coreana & KT030261 & S. Baek, 2015, unpublished data \\
\hline & Amphiascoides atopus & KC815328 & $\begin{array}{l}\text { Gomez,S. et al., 2013, } \\
\text { unpublished data }\end{array}$ \\
\hline & Diosaccus ezoensis & KR048740 & S. Baek, 2015, unpublished data \\
\hline & Miracia efferata & EU380294 & $\begin{array}{l}\text { Huys, Mackenzie-Dodds } \\
\text { \& Llewellyn-Hughes (2009) }\end{array}$ \\
\hline & Paramphiascella fulvofasciata & EU380293 & $\begin{array}{l}\text { Huys, Mackenzie-Dodds } \\
\text { \& Llewellyn-Hughes (2009) }\end{array}$ \\
\hline & Stenhelia sp. & EU380291 & $\begin{array}{l}\text { Huys, Mackenzie-Dodds } \\
\text { \& Llewellyn-Hughes (2009) }\end{array}$ \\
\hline & Typhlamphiascus typhlops & EU380292 & $\begin{array}{l}\text { Huys, Mackenzie-Dodds } \\
\text { \& Llewellyn-Hughes (2009) }\end{array}$ \\
\hline & Sarsamphiascus hawaiiensis & MN496455 & This paper \\
\hline & Sarsamphiascus hawaiiensis & MN496456 & This paper \\
\hline & Sarsamphiascus kawamurai & MN541391 & This paper \\
\hline & Sarsamphiascus kawamurai & MN541392 & This paper \\
\hline & Sarsamphiascus kawamurai & MN541393 & This paper \\
\hline & Sarsamphiascus kawamurai & MN541394 & This paper \\
\hline & Dactylopusia pauciarticulata & KR048735 & S. Baek, 2015, unpublished data \\
\hline & Thalestridae sp. & MF077761 & Khodami,S. et al. (2017) \\
\hline \multirow[t]{10}{*}{$\mathrm{COI}$} & Amonardia coreana & KT030279 & S. Baek, 2015, unpublished data \\
\hline & Amonardia normani & MH242652 & $\begin{array}{l}\text { Leray,M. \& Paulay,G., 2018, } \\
\text { unpublished data }\end{array}$ \\
\hline & Amonardia perturbata & MH242653 & $\begin{array}{l}\text { Leray,M. \& Paulay,G., 2018, } \\
\text { unpublished data }\end{array}$ \\
\hline & Amphiascoides atopus & KF667526 & Easton,E.E. et al. (2014) \\
\hline & Amphiascoides sp. & MH242654 & $\begin{array}{l}\text { Leray,M. \& Paulay,G., 2018, } \\
\text { unpublished data }\end{array}$ \\
\hline & Amphiascopsis cinctus & MH670487 & $\begin{array}{l}\text { Rossel,S. \& Martinez Arbizu,P. } \\
(2019)\end{array}$ \\
\hline & Amphiascus sp. & KX714910 & Gollner,S. et al. (2016) \\
\hline & Bulbamphiascus imus & MH670542 & $\begin{array}{l}\text { Rossel,S. \& Martinez Arbizu,P. } \\
\text { (2019) }\end{array}$ \\
\hline & Delavalia palustris & MH976534 & $\begin{array}{l}\text { Rossel,S. \& Martinez Arbizu,P. } \\
\text { (2019) }\end{array}$ \\
\hline & Delavalia reflexa & MH976545 & $\begin{array}{l}\text { Rossel,S. \& Martinez Arbizu,P. } \\
\text { (2019) }\end{array}$ \\
\hline
\end{tabular}




\begin{tabular}{|c|c|c|}
\hline Diosaccus ezoensis & KR049013 & S. Baek, 2015, unpublished data \\
\hline Diosaccus spinatus & MH242730 & $\begin{array}{l}\text { Leray,M. \& Paulay,G., 2018, } \\
\text { unpublished data }\end{array}$ \\
\hline Eoschizopera sp. & MH976580 & $\begin{array}{l}\text { Rossel,S. \& Martinez Arbizu,P. } \\
\text { (2019) }\end{array}$ \\
\hline Haloschizopera pygmaea & MH976598 & $\begin{array}{l}\text { Rossel,S. \& Martinez Arbizu,P. } \\
\text { (2019) }\end{array}$ \\
\hline Haloschizopera sp. & MH976605 & $\begin{array}{l}\text { Rossel,S. \& Martinez Arbizu,P. } \\
\text { (2019) }\end{array}$ \\
\hline Itostenhelia golikovi & KF524864 & $\begin{array}{l}\text { Karanovic,T., Kim,K. \& Lee,W. } \\
(2014)\end{array}$ \\
\hline Itostenhelia polyhymnia & KF524868 & $\begin{array}{l}\text { Karanovic,T., Kim,K. \& Lee,W. } \\
\text { (2014) }\end{array}$ \\
\hline Macrosetella gracilis & MG742365 & $\begin{array}{l}\text { Santhanam,P. et al., 2017, } \\
\text { unpublished data }\end{array}$ \\
\hline Miracia efferata & GU171350 & Bucklin,A. et al. (2010) \\
\hline Sarsamphiascus hawaiiensis & MN507530 & This paper \\
\hline Sarsamphiascus kawamurai & MN542379 & This paper \\
\hline Sarsamphiascus kawamurai & MN542380 & This paper \\
\hline Sarsamphiascus undosus & MH242965 & $\begin{array}{l}\text { Leray,M. \& Paulay,G., 2018, } \\
\text { unpublished data }\end{array}$ \\
\hline Schizopera akation & JQ390560 & $\begin{array}{l}\text { Karanovic,T. \& Cooper,S.J.B. } \\
\text { (2012) }\end{array}$ \\
\hline Schizopera akolos & JQ390584 & $\begin{array}{l}\text { Karanovic,T. \& Cooper,S.J.B. } \\
\text { (2012) }\end{array}$ \\
\hline Schizopera analspinulosa & JQ390588 & $\begin{array}{l}\text { Karanovic,T. \& Cooper,S.J.B. } \\
\text { (2012) }\end{array}$ \\
\hline Schizopera emphysema & JQ390558 & $\begin{array}{l}\text { Karanovic,T. \& Cooper,S.J.B. } \\
\text { (2012) }\end{array}$ \\
\hline Schizopera knabeni & KF667527 & Easton,E.E. et al. (2014) \\
\hline Schizopera kronosi & JQ390567 & $\begin{array}{l}\text { Karanovic,T. \& Cooper,S.J.B. } \\
(2012)\end{array}$ \\
\hline Schizopera leptafurca & JQ390590 & $\begin{array}{l}\text { Karanovic,T. \& Cooper,S.J.B. } \\
(2012)\end{array}$ \\
\hline Schizopera uranusi & JQ390561 & $\begin{array}{l}\text { Karanovic,T. \& Cooper,S.J.B. } \\
(2012)\end{array}$ \\
\hline Stenhelia pubescens & KF524870 & $\begin{array}{l}\text { Karanovic,T., Kim,K. \& Lee,W. } \\
\text { (2014) }\end{array}$ \\
\hline Stenhelia taiae & KF524885 & $\begin{array}{l}\text { Karanovic,T., Kim,K. \& Lee,W. } \\
\text { (2014) }\end{array}$ \\
\hline Wellstenhelia calliope & KF524872 & $\begin{array}{l}\text { Karanovic,T., Kim,K. \& Lee,W. } \\
\text { (2014) }\end{array}$ \\
\hline Wellstenhelia clio & KF524873 & Karanovic,T., Kim,K. \& Lee,W. \\
\hline
\end{tabular}


Wellstenhelia qingdaoensis $\quad$ KF524874 Karanovic,T., Kim,K. \& Lee,W. (2014)

Willenstenhelia thalia KF524882 Karanovic,T., Kim,K. \& Lee,W. (2014)

2 
Table 3 (on next page)

Setal formula of the new species. 
1 Table 3: Setal formula of the new species.

2

\begin{tabular}{ccc}
\hline & Endopod & Exopod \\
\hline $\mathrm{P} 1$ & 1.0 .030 & 0.0 .023 \\
& & \\
$\mathrm{P} 2$ & 1.2 .121 & 1.1 .123 \\
& & \\
$\mathrm{P} 3$ & 1.1 .321 & 1.1 .123 \\
& & \\
$\mathrm{P} 4$ & 1.1 .221 & 1.1 .323 \\
\hline
\end{tabular}




\section{Table 4(on next page)}

Estimates of average evolutionary divergence over sequence pairs within Miraciidae genera based on mitochondrial cytochromeoxidase I (mtCOI) gene data.

This table only includes genera in which more than two species of data exist. 
1 Table 4: Estimates of average evolutionary divergence over sequence pairs within Miraciidae

2 genera based on mitochondrial cytochrome oxidase I (mtCOI) gene data.

\begin{tabular}{cccc}
\hline & $\begin{array}{c}\text { Mean distance } \\
\text { within genus }\end{array}$ & $\begin{array}{c}\text { Standard } \\
\text { error }\end{array}$ & $\begin{array}{c}\text { Number of } \\
\text { species included }\end{array}$ \\
\hline Amonardia & 0.235 & 0.017 & 3 \\
\hline Amphiascoides & 0.238 & 0.022 & 2 \\
\hline Delavalia & 0.340 & 0.027 & 2 \\
\hline Diosaccus & 0.232 & 0.021 & 2 \\
\hline Haloshizopera & 0.256 & 0.020 & 2 \\
\hline Itostenhelia & 0.055 & 0.010 & 4 \\
\hline Sarsamphiascus & 0.206 & 0.014 & 8 \\
\hline Schizopera & 0.244 & 0.013 & 2 \\
\hline Stenhelia & 0.225 & 0.020 & 3 \\
\hline Wellstenhelia & 0.231 & 0.018 & 2
\end{tabular}

3 This table only includes genera in which more than two species of data exist. 